Finally, Claude Gillot was a man of great modesty and immense kindness and, for that reason, loved by all.

I wholeheartedly consider the great opportunity which I was gifted being his disciple, allowing me to share his immense knowledge in human anatomy, that he did with humility and simplicity.

'Au revoir, mon cher Claude', you will be forever present in our heart.

Docteur Jean-François UHL

\section{Professor Paolo Fiorani: "Maestro" of a generation of vascular surgeons}

Prof. Paolo Fiorani: ricordo di un allievo

\section{Spartera ${ }^{1}$}

${ }^{1}$ Emeritus Professor of Vascular Surgery. Univerisity of L'Aquila, Italy submitted: Oct 17, 2018, accepted: Oct 17, 2018, EPub Ahead of Print: Dec 9, 2018, published: Jul 7, 2019 Conflict of interest: none

DOI: 10.24019/jtavr.52 - Corresponding author: Prof. Carlo Spartera, carlo.spartera@tin.it

(C) 2018 Fondazione Vasculab impresa sociale ONLUS. All rights reserved.

\section{ITALIANO}

Dal maggio scorso non è più tra noi il Professor Paolo Fiorani, chirurgo vascolare, maestro di scienza e di vita. (Fig. 1)

Il suo curriculum e la sua carriera sono noti a tutti, essendo stato un punto di riferimento accademico e chirurgico in questi ultimi 50 anni, periodo eccezionalmente innovativo nel campo medico e chirurgico, in particolare nella chirurgia vascolare.

Il Professor Fiorani ha vissuto questi anni in prima linea, da protagonista.

L'avventura inizia negli anni '60, periodo in cui tre grandi ed illuminati chirurghi, Malan a Milano, Stefanini a Roma e Zannini a Napoli, capiscono che è arrivato il momento in cui alcune specialità, come la chirurgia dei trapianti, la chirurgia toracica e la chirurgia vascolare, si rendano indipendenti sia dal punto di vista clinicochirurgico che accademico.
In quegli anni il Prof Fiorani frequenta come "fellow" il Baylor College of Medicine a Houston, presso il Dipartimento di Chirurgia Cardio-vascolare diretto dal grande Prof Michael De Backey.

Tornato in Italia, Egli porta nella chirurgia vascolare italiana quanto appreso e sperimentato negli Stati Uniti, dando così il via alla ricerca clinica nei settori della chirurgia vascolare in veloce espansione (chirurgia dell'arteria renale e ipertensione renovascolare; chirurgia della carotide ed insufficienza cerebrovascolare; patologia arteriosa degli arti). Inoltre, può essere considerato pioniere della chirurgia dell'aorta addominale in Italia.

Il Prof Fiorani è stato sicuramente uno dei padri della chirurgia vascolare italiana e ne ha rappresentato i valori in Europa e nel mondo, instaurando scambi costruttivi con i maggiori rappresentanti del settore quali Courbier e Kieffier in Francia, Balas in Grecia, Vollmar in Germania, Greenhalgh in Inghilterra, Imparato, Wiley e Veith negli Stati Uniti con i quali ha contribuito al grande sviluppo della Chirurgia Vascolare Open.

Quando poi, negli anni '90, sono state introdotte le tecniche mini invasive, sia chirurgiche che endovascolari, egli ha subito capito l'importanza di tali tecniche, riconoscendone l'impatto positivo nella pratica clinica e nella ricerca.

Infatti nella Chirurgia Vascolare della $2^{\circ}$ clinica chirurgica dell'Università la Sapienza di Roma è stata impiantata una endoprotesi aortica (una delle prime in Italia) con l'ausilio del suo inventore argentino prof. Parodi.

Con la sua esperienza e sotto la sua guida si è formata la Scuola di Chirurgia Vascolare Romana ${ }^{[i]}$ (Fig. 2) ed inoltre Egli ha partecipato fattivamente alla fondazione della Società Italiana di Chirurgia Vascolare.

E' stato il primo italiano ad essere Presidente della Società Europea di Chirurgia Vascolare, conosciuto e stimato anche da colleghi di altre specialità con i quali ha collaborato in varie ricerche, tra cui importantissimi gli studi sul circolo cerebrale che ha condiviso con gruppi di ricerca internazionali, quali quello di Lassen in Danimarca, con la collaborazione e la grande competenza specifica del Prof Pistolese

E' stato il primo italiano Socio Onorario della Società Americana di Chirurgia Vascolare.

Con Lui scompare un pilastro dalle fondamenta della chirurgia vascolare italiana e noi allievi, G. Raimondo Pistolese Università Tor Vergata Roma, Vittorio Faraglia e poi Maurizio Taurino al Sant'Andrea Roma Università la Sapienza, Francesco Spaziale al Policlinico Università la Sapienza Roma ed il sottoscritto all'Università de L'Aquila, che abbiamo iniziato sotto la sua spinta energica la carriera 
di chirurghi vascolari, ricorderemo sempre la sua sagacia, il suo impulso quotidiano a migliorarsi, la sua curiosità scientifica, le sue intuizioni geniali, doti che hanno fatto di Lui un vero Maestro.

Ma non posso fare a meno, in questa circostanza, di ricordare il lato umano del Prof Fiorani: egli amava la vita e la convivialità e lo ha dimostrato aprendo la sua casa per tante cene postcongressuali, con il supporto costante della moglie Paola con cui ha formato una splendida famiglia con 5 figli.

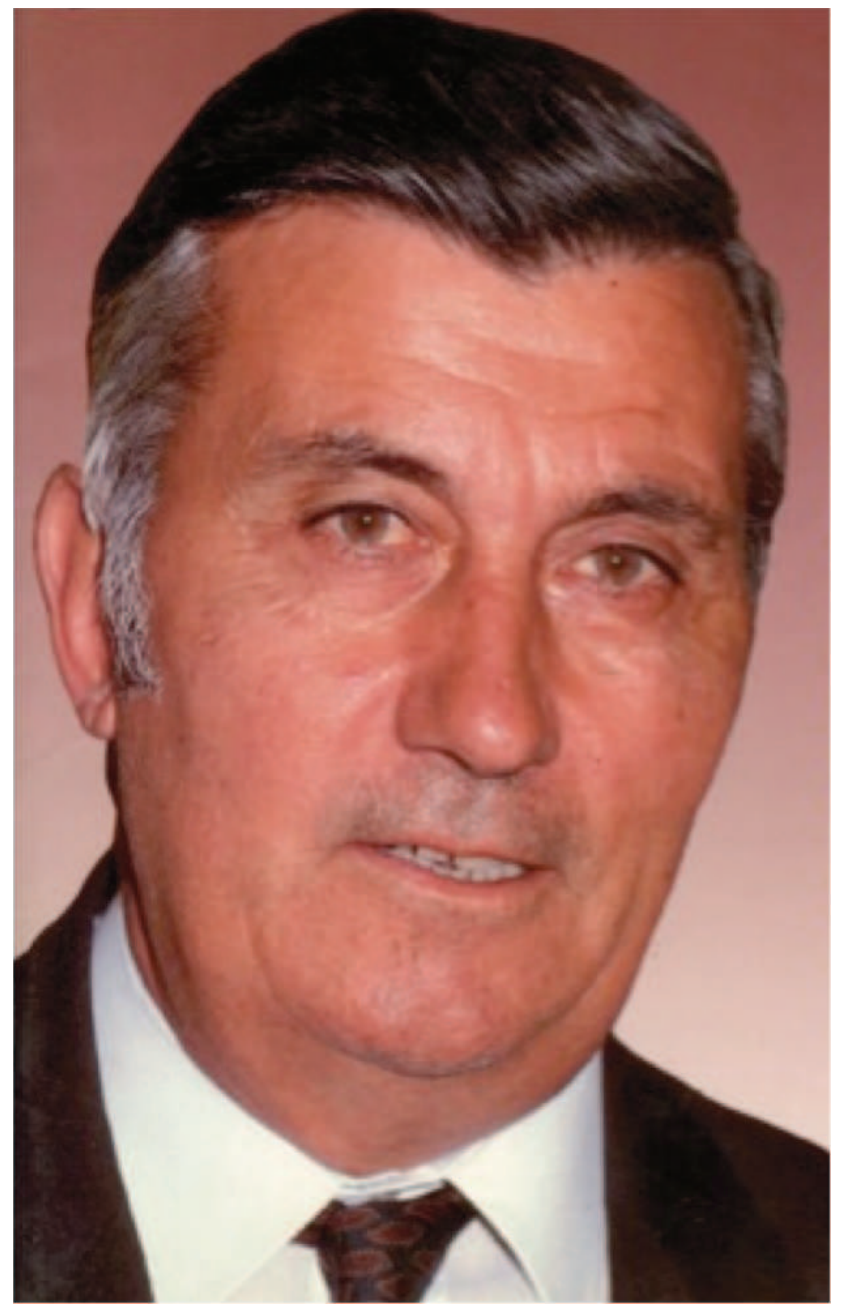

Figure 1 - Prof. Paolo Fiorani

\section{ENGLISH}

Since last May, Professor Paolo Fiorani, vascular surgeon, Maestro of science and of life, has no longer been with us. (Fig. 1)

His curriculum and his career are known to all, his having been an academic and surgical reference point during the last 50 years, an exceptionally innovative period
Ci legava il tifo romanista ed era anche un grande sportivo: amava lo sci, il mare e la barca a vela, buon tennista e ottimo golfista nel quale sport si racconta di accanite partite col suo grande amico Raimondo Pistolese.

Ora non c'è più, ma credo che il Professor Fiorani mancherà molto a tutto il mondo scientifico ed accademico italiano ed internazionale.

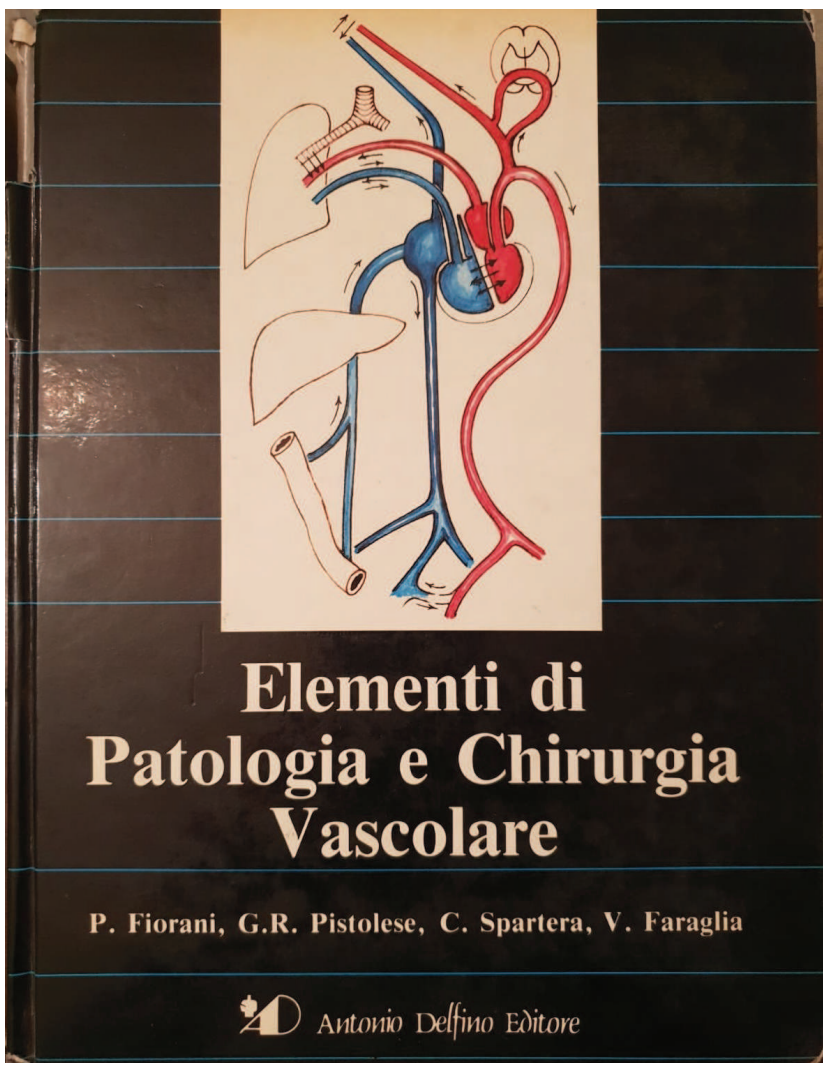

Figure 2 - Fiorani P, Pistolese GR, Spartera C, Faraglia V. Elementi di Patologia e Chirurgia Vascolare. [Basics of Pathology and Vascular Surgery]. Antonio Delfino Ed., 1988. ISBN: 8872870348.

in the field of medicine and surgery, in particular in vascular surgery.

Professor Fiorani lived these years on the front line, as a protagonist.

His adventure starts in the 1960s, a period in which the great and farsighted surgeons Malan in Milan, Stefanini in Rome and Zannini in Naples, understood that the time had come for some specialities, like transplant 
surgery, thoracic surgery and vascular surgery, to become independent both from a clinical-surgical point of view and academically.

In those years Prof. Fiorani was a Fellow of the Baylor College of Medicine in Houston, at the Department of Cardiovascular Surgery directed by the great Prof. Michael De Backey.

Having returned to Italy, he brought what he had learnt and experienced in the United States to Italian vascular surgery, thereby setting off clinical research in fast-expanding sectors of vascular surgery (surgery of the renal artery and renovascular hypertension; carotid surgery for cerebrovascular insufficiency; peripheral arterial disease). Besides, he may be considered the pioneer of abdominal aorta surgery in Italy.

Professor Fiorani was certainly one of the fathers of Italian vascular surgery he represented its values in Europe and the world, setting up constructive exchanges with major representatives of the sector like Courbier and Kieffer in France, Balas in Greece, Vollmar in Germany, Greenhalgh in England and Imparato, Wiley and Veith in the USA, with whom he contributed to the notable development of Open Vascular Surgery.

In the 1990s, when both surgical and endovascular mini-invasive techniques were introduced, he immediately understood the importance of such techniques, recognising their positive impact in clinical practice and in research.

In fact, in the Vascular Surgery Unit of the 2nd Department of Surgery of La Sapienza University in Rome an aortic endoprothesis was implanted (one of the first in Italy) with the assistance of its Argentine inventor Prof. Parodi.

With his experience and under his guidance the Roman School of Vascular Surgery ${ }^{[i i]}$ (Fig. 2) formed and he also actively participated in the foundation of the Italian Society of Vascular Surgery.

He was the first Italian to be President of the European Society of Vascular Surgery, and was also recognised and

\section{Endnotes}

[i] Mi fa piacere aggiungere al ricordo del Prof. Fiorani la foto del frontespizio di un libro edito alla fine degli anni '80. E' una pubblicazione di circa 500 pagine, con schemi anatomici, foto di esami diagnostici e documentazioni intraoperatorie indirizzata agli studenti e agli specializzandi in chirurgia vascolare, edito da Delfino, allora all'avanguardia nell'editoria medico-scientifica. Il volume rappresenta, almeno in parte, ciò che ha significato, per gli autori, vivere la nascita, la giovinezza e la maturità della chirurgia vascolare italiana. Infatti, il volume racchiude l'esperienza di 20 anni del gruppo di chirurgia vascolare romano vissuta sul campo ed affronta $\mathrm{i}$ diversi aspetti della fisiologia e fisiopatologia della clinica, della diagnostica e della esteemed by colleagues from other specialities, with whom he collaborated in various research projects, among the most important of which were the studies of the cerebral blood flow that he shared with the international research groups, like that of Lassen in Denmark, with cooperation and great specific competence of Prof Pistolese.

He was the first Italian to be an Honorary Member of the American Society of Vascular Surgery.

His passing is also the disappearance a foundation pillar of Italian vascular surgery, and we, his former assistants and then colleagues, G. Raimondo Pistolese at Tor Vergata University of Rome, Vittorio Faraglia and then Maurizio Taurino at Sant'Andrea La Sapienza University of Rome, Francesco Speziale at Policlinic of La Sapienza University of Rome, and the undersigned at the University of Aquila, that initiated our careers as vascular surgeons under his energetic impetus shall always remember his wisdom, his daily efforts to better himself, his scientific curiosity and his brilliant insights, gifts that made him a true Maestro.

But in this circumstance, I cannot but recall the human side of Prof. Fiorani: he loved life and conviviality and demonstrated this by opening his house for numerous post-congress dinners, with the constant support of his wife Paola, with whom he had made a splendid family with five children.

We were linked by being fans of Rome F.C. and he was also a great sportsman: he loved skiing, the sea and sailing, was good at tennis and a fine golfer, a sport in which there are stories of tough matches with his great friend Raimondo Pistolese.

Now he has passed away, but I believe that Professor Fiorani shall be greatly missed by the entire Italian and international scientific and academic world.

\section{Prof. Carlo Spartera}

Emeritus Professor of Vascular Surgery.

Univerisity of L'Aquila, Italy

terapia delle patologie vascolari, arteriose e venose. Naturalmente, da quegli anni la chirurgia vascolare ha fatto passi da giganti nella modernizzazione dell'approccio e della soluzione di molte problematiche che allora sembravano insormontabili. Tuttavia, credo che il libro possa essere ancora molto utile a chi affronta, per la prima volta, tale settore scientifico-disciplinare.

[ii] I am pleased to add this photograph of the cover of a book published at the end of the 1980s to the commemoration of Prof. Fiorani. It is a publication of about 500 pages, with anatomical diagrams, photos of diagnostic exams and intraoperative documentation aimed 
at students and at doctors specialising in vascular surgery, published by Delfino, then in the avant-garde of the medical-scientific press. At least in part, the volume shows what it meant, for the authors, to live through the birth, growth and maturity of Italian vascular surgery. In fact, the volume captures the 20-year experience in the field of the Roman vascular surgery group and deals with the different aspects of the physiology and physiopathology of the clinical presentation, diagnostics and therapy of arterial and venous vascular pathologies. Naturally, since that time vascular surgery has made giant steps in the modernisation of the approach and the solution of many problems that then seemed insurmountable. However, I believe that the book may still be very useful to anyone approaching this scientific-disciplinary sector for the first time. 